rocks and unrelated to the tectonic structure of the pre-Carboniferous deposits. Later, with Prof. W. G. Fearnsides, he extended his physiographic studies to the Howgill Fells.

As a writer and exponent of scientific facts and principles, Marr had a lucidity and ease of expression that made his work not only an education, but also a pleasure to peruse. His numerous separately published memoirs and textbooks all present this character, and it is only necessary to turn to his work on the "Scientific Study of Scenery" to see how great was his capacity for presenting essential facts in an interesting and attractive manner.

Although by virtue of his scientific achievements and the importance of his publications Marr takes a place in the foremost rank of British geologists, it is as a teacher, first as lecturer and then as Woodwardian professor at Cambridge, that he will be gratefully remembered by a host of past students and by a band of devoted and loyal colleagues. Marr's influence on the Cambridge school of geology since his appointment as lecturer in 1886 has been enormous. He was responsible for the teaching of all the stratigraphical and physical geology, both elementary and advanced, and with the then Woodwardian professor, $T$. McKenny Hughes, and with the able collaboration of Alfred Harker and Henry Woods, was largely instrumental in making Cambridge the foremost school of geology in Britain. $\mathrm{He}$ was appointed Woodwardian professor in succession to Prof. Hughes in 1917, a position which he assumed to everyone's satisfaction, and which he filled with traditional distinction. His failing sight, however, and an indisposition from which he never completely recovered, caused him to retire from the chair in 1930, but he retained all his mental vigour and his intense interest in geology and the Cambridge school until the end.

Outside Cambridge, Marr also played throughout his life an important part in geological activities. He served on the council of the Geological Society almost continuously for forty years, being secretary for ten years, president from 1904 until 1906 , and foreign secretary from 1925 until 1928. $\mathrm{He}$ received at different times three medals from the Society in recognition of the value of his services to geology, culminating in the highest award, the Wollaston medal, in 1914. He was awarded a Royal medal by the Royal Society in 1930; he was elected a fellow of the Royal Society so long ago as 1891 .

A naturally courteous and chivalrous nature coupled with an immensity of human understanding made Marr approachable in his official capacity, and a delightful host and companion. His students invariably received from him just that encouragement in their work and that individual interest which stirred them to endeavour. His house was open to them, and with the kindly assistance of Mrs. Marr this privilege of personal contact was enjoyed by generations of undergraduates, most of whom came as pupils and left as devoted friends.

\section{Mr. E. Everett}

OLD students of the Carendish Laboratory will regret to hear that $\mathrm{Mr}$. E. Everett died on November 4 at the age of sixty-eight years. He went from the Chemical Laboratory to the Cavendish in 1888 as private assistant to the professor and remained there until 1930, when his health broke down. It was hoped that the rest might enable him to recover sufficiently to be able to enjoy the leisure he had earned so well, but it was not so, and he remained an invalid and suffered much pain and discomfort until his death.

Everett took a very active and important part in the researches carried on in the Laboratory, by students as well as by the professor. The great majority of these involved difficult glass blowing, which was nearly all done by Everett, as it was beyond the powers of most of the students. In addition to this, he made all the apparatus used in my experiments for the more than forty years in which he acted as my assistant. I owe more than I can express to his skill and the zeal which he threw into his work. He was a very skilful glass blower, a quick worker, very pertinacious; if the first method failed he would try another and generally succeeded in finding one which would work. He was also an excellent lecture assistant, and was a great help to me in my lectures at the Royal Institution. He took a personal interest in the success of each experiment and spared neither time nor trouble to make it come off.

In the early days of X-rays, before hospitals or medical men had any appliances for taking X-ray photographs, Everett and W. H. Hayles, another assistant at the Cavendish Laboratory and an expert photographer, organised a scheme for taking photographs at the Laboratory. Many medical men availed themselves of this, although the revelations made by the photographs as to the way in which bones had been set sometimes caused considerable embarrassment.

Everett's services to the Cavendish Laboratory were recognised by the University of Cambridge, which in 1931 conferred upon him the honorary degree of M.A. Of this he was rightly very proud, and it was, I believe, a great consolation to him in his troubles.

J. J. Thомson.

We regret to announce the following deaths:

Mr. W. H. Fowler, C.V.O., consulting radiologist to Edinburgh Royal Infirmary, an authority on radium and radiology, on October 5, aged fiftyseven years.

Dr. Ernst Hartert, director of the Zoological (Rothschild) Museum, Tring, from 1892 until 1930, on November 11, aged seventy-three years.

Lieut.-Col. C. G. Nurse, a well-known entomologist, who published numerous papers chiefly on the Hymenoptera of India, on November 5, aged seventy-one years. 